\title{
Business Cycles and Distribution of Wages in Colombia: A Semi-Parametric Wage Density Decomposition Approach
}

\author{
Received: April 9, 2020 - Accepted: July 20, 2020
}

Doi: https://doi.org/10.12804/revistas.urosario.edu.co/economia/a.8925

Jimmy Melo*

\section{Highlights}

- The cyclical tightening of labor markets ends up shifting wage distribution to the left.

- Semi-parametric decomposition illustrates factors shaping wage distribution along a business cycle.

- Minimum wage setting can induce a positive spillover over a recovery phase.

- Procyclicality of real wages is associated to shifts in labor demand and supply factors.

- Wage density translations on a cycle depend on secular factors such as skills updating.

* Economics Department, Universidad Central,Colombia. E-mail:jmelom@ucentral. edu.co orCID: https://orcid.org/0000-0002-7301-4337

To quote this article: Melo, J. (2020). Business Cycles and Distribution of Wages in Colombia: A Semi-Parametric Wage Density Decomposition Approach. Revista de Economía del Rosario, 23(2), 1-21. https://doi.org/10.12804/revistas.urosario.edu.co/economia/a.8925 


\begin{abstract}
This paper examines the changes in real hourly wages in Colombia along the recovery phase from March 2009 to March 2014. The research starts from the fact that the distribution of wages at trough looks like translations to the left of recovery distribution. This paper sheds light on those procyclical translations through a sequential decomposition on the change of wages in 1) cyclical demand and supply factors; 2) changes in the workers' attributes; 3 ) changes and spillover effects of the minimum wage, and 4) residual. As the literature suggests, this paper confirms that real hourly wages procyclicality is associated, mainly, with shifts on labor demand and supply factors, and to skills updating —usually linked to the wage distribution secular trend. As a novelty, evidence suggests that there is a positive spillover from monthly minimum wage on hourly wages, explaining $25 \%$ of the divergence between distributions.
\end{abstract}

Keywords: Business cycles; wage differentials; wage distribution; labor market; minimum wage.

JEL classification: E24, E32, J20, J31, C14

\title{
Ciclo econômico e distribuição salarial na Colômbia: Um enfoque semi-paramétrico de decomposição da densidade salarial
}

\section{Resumo}

Este artigo examina as mudanças nos salários reais por hora na Colômbia ao longo da fase de recuperação que teve lugar entre março de 2009 e março de 2014. Parte-se da observação que a distribuição dos salários no vale parece como uma translação à esquerda da distribuição na recuperação. Este artigo interpreta essa translação pró-cíclica mediante uma decomposição sequencial da variação dos salários em 1) fatores cíclicos de oferta y demanda; 2) mudanças nos atributos dos trabalhadores; 3) mudanças e efeitos transbordamento gerados pelo salário mínimo, e 4) residual. Como sugere a literatura, este trabalho confirma que o comportamento pró-cíclico dos salários reais por hora está associado, principalmente, com mudanças nos fatores de oferta e demanda laboral, e com a atualização de habilidades, geralmente ligada à tendência secular da distribuição salarial. Como novidade, a evidência sugere que existe um efeito transbordamento positivo do salário mínimo mensal sobre os salários por hora, o qual explica o $25 \%$ da divergência entre as distribuições.

Palavras-chave: Ciclos econômicos, diferenciais salariais, distribuição salarial, mercado laboral, salário mínimo.

\section{Ciclo económico y distribución salarial en Colombia: Un enfoque semiparamétrico de descomposición de la densidad salarial}

Resumen

Este artículo examina los cambios en los salarios reales por hora en Colombia a lo largo de la fase de recuperación que tuvo lugar entre marzo de 2009 y marzo de 2014 . Se parte de la observación de que la distribución de los salarios en el valle luce como una traslación a 
la izquierda de la distribución en la recuperación. Este artículo interpreta esa translación procíclica mediante una descomposición secuencial de la variación de los salarios en 1) factores cíclicos de oferta y demanda; 2) cambios en los atributos de los trabajadores; 3) cambios y efectos desbordamiento generados por el salario mínimo, y 4) residual. Como sugiere la literatura, este trabajo confirma que el comportamiento procíclico de los salarios reales por hora está asociado, principalmente, con cambios en los factores de oferta y demanda laboral, y con la actualización de habilidades, generalmente ligada a la tendencia secular de la distribución salarial. Como novedad, la evidencia sugiere que existe un efecto desbordamiento positivo del salario mínimo mensual sobre los salarios por hora, el cual explica el $25 \%$ de la divergencia entre las distribuciones.

Palabras clave: Ciclos económicos, diferenciales salariales, distribución salarial, mercado laboral, salario mínimo.

\section{Introduction}

Evidence and theory suggest that hourly mean real wages are procyclical. For the us, Barsky and Solon (1989) provided evidence linking it with changes in employment opportunities, while Barlevy and Tsiddon (2004) argued that fluctuations of wage distribution on a particular cycle depend on the wage distribution secular trend. For the Colombian case, Arango et al. (2016) showed that mean hourly wages are procyclical and emphasized the lag on the literature regarding the whole distribution and the factors to explain that procyclical behavior.

Following DiNardo, Fortin, and Lemieux's (1996) methodology (DFL methodology), this paper examines the changes in Colombia's distribution of real hourly mean wages from the trough to the recovery at the cycle from January 2008 to March 2014 (Arango, Parra-Escobar, \& Pinzón-Giraldo, 2016). That is, implementing a semi-parametric wage density decomposition by estimating the counterfactual "density that would have prevailed if individual attributes had remained at their (...trough] level and workers had been paid according to the wage schedule observed in (...recovery)" (DiNardo, Fortin, \& Lemieux, 1996, p. 1011).

As a starting observation, the distribution of wages at trough (March 2009) looks like translations to the left of the recovery wage distribution (March 2014), in order to give an account of that movement, I propose that differences in the wage distribution can be decomposed in 1) cyclical demand and supply factors, 2) changes in workers' attributes, 3) changes and spillovers effects of the minimum wage, and 4) a residual associated to seasonal and long-run effects on the labor market.

Using the DFL methodology, this paper presents evidence on factors shaping wage distribution in recovery. Real hourly wages procyclicality is 
associated both with responses of wage schedules labor demand-supply and macroeconomic developments and to the wage distribution secular trend. The sequential decomposition incorporates responses of the wage schedule by cells looking for a narrower definition of skill groups and accounts for the role of individual attributes. The evidence derived suggests that there is a positive spillover from monthly minimum wage on hourly wages, explaining $25 \%$ of the divergence between trough and recovery distributions.

The paper is organized as follows. Section 1 describes the timing of the cycle, sample, and variables used to perform estimations. Section 2 shows details on the DFL sequential decomposition between trough and recovery and presents its results. Section 3 discusses the main findings and presents concluding remarks.

\section{Business Cycle Timing for Sampling and Estimation}

There are three criteria to define the timing of a business cycle: duration, depth, and diffusion (Alfonso et al., 2012; Moore, 1983). As suggested by Moore (1983):

Diffusion indexes are useful not only to measure the extent to which a contraction has spread throughout the economy, but also to determine the approximate date when the balance turned from expansion to contraction. (...) Diffusion indexes portray this changing balance in various ways depending upon their composition and method of construction (p. 8).

Following this approach, Alfonso et al. (2012) proposed a timing for business cycles in Colombia —updated by Arango et al. (2016). Using that timing, this paper concentrated on the cycle from January 2008 to March 2014. The trough happened in March 2009, and the recovery peak in March 2014. Figure 1 presents the Monthly Index of Economic Activity (IMAco for its acronym in Spanish), defined as "a monthly indicator constructed by the technical team of the Central Bank of Colombia based on sectorial variables, which anticipates in five months the movements of the annual GDP growth accumulated four quarters" (Banco de la República, 2019).

The IMACO is a broad indicator linking Colombia's Central Bank's projection of the performance of the economy at a given date with the information of the projected course of the economy (Kamil, Pulido, \& Torres, 2010). In addition, figure 1 includes the monthly annual GDP growth accumulated four 
quarters and the date assigned for the trough. The lack of growth negative rates display shows that the 2008-2014 cycle was a growth deceleration episode. Nevertheless, duration, depth, and diffusion matter in defining the timing for a cycle; consequently, there is no match between the timing suggested by the broad or the timing suggested sectorial indicators, taken separately.

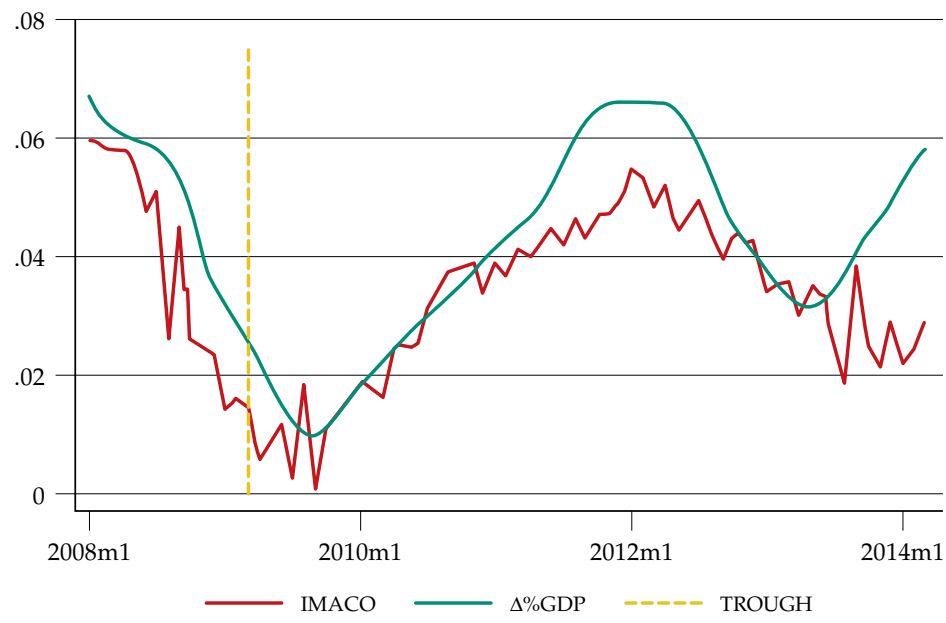

Figure 1. IMACO and Monthly Rate of Annual Growth

Source: Central Bank of Colombia and Arango et al. (2016).

This paper uses data from the Large Integrated Household Survey (GEIH for its Spanish acronym) to analyze changes in the distribution of hourly wages in Colombia from 2008 to 2014. To make sample reporting comparable, I used each year's March GEIH ameliorating seasonal effects and wages' misreporting - workers reported previous year wages during January and February, inducing overestimation of decreasing wages. Relatively large samples of workers are available to estimate changes in the distribution of hourly wages along the cycle. The sample sizes are approximately 29000 workers per month, which are intended to be representative of the Colombian labor market. Table 1 clearly presents the differences in attributes between female and male workforce. Using the percentage of the workers earning less than the legal minimum wage as an indirect measure of informality, it is possible to suggest that informality is procyclical. Improvements in formality emerge from the recovery; nonetheless, those improvements are unevenly distributed across female and male segments of the labor market. 
Table 1. Attributes: Means GEIH

\begin{tabular}{|c|c|c|c|c|c|c|c|}
\hline & March & OBS & Years of Schooling & Tenure & Age & $\begin{array}{l}\text { Under- } \\
\text { Employment Rate }\end{array}$ & $\begin{array}{l}\text { Informality } \\
\text { Indicator }\end{array}$ \\
\hline \multirow{7}{*}{$\begin{array}{l}\text { Whole } \\
\text { Sample }\end{array}$} & 2008 & 26750 & 9.40 & 6.58 & 38.22 & $29.95 \%$ & $43.85 \%$ \\
\hline & 2009 & 27039 & 9.20 & 6.99 & 37.97 & $28.68 \%$ & $45.06 \%$ \\
\hline & 2010 & 28106 & 9.44 & 6.93 & 38.33 & $30.44 \%$ & $44.23 \%$ \\
\hline & 2011 & 29670 & 9.52 & 6.58 & 38.44 & $30.76 \%$ & $43.59 \%$ \\
\hline & 2012 & 30071 & 9.61 & 6.29 & 38.78 & $29.85 \%$ & $40.79 \%$ \\
\hline & 2013 & 28706 & 9.69 & 6.58 & 38.71 & $28.61 \%$ & $40.27 \%$ \\
\hline & 2014 & 29033 & 9.85 & 6.63 & 38.99 & $26.10 \%$ & $41.04 \%$ \\
\hline \multirow{7}{*}{ Female } & 2008 & 11684 & 10.25 & 5.24 & 37.98 & $29.73 \%$ & $43.91 \%$ \\
\hline & 2009 & 11784 & 10.07 & 5.61 & 37.84 & $28.42 \%$ & $44.54 \%$ \\
\hline & 2010 & 12441 & 10.24 & 5.73 & 38.19 & $31.25 \%$ & $43.70 \%$ \\
\hline & 2011 & 13156 & 10.33 & 5.65 & 38.75 & $31.90 \%$ & $44.78 \%$ \\
\hline & 2012 & 13645 & 10.33 & 5.24 & 38.97 & $29.80 \%$ & $42.21 \%$ \\
\hline & 2013 & 12946 & 10.42 & 5.43 & 38.54 & $29.88 \%$ & $40.36 \%$ \\
\hline & 2014 & 13173 & 10.53 & 5.32 & 38.81 & $27.23 \%$ & $42.09 \%$ \\
\hline \multirow{7}{*}{ Male } & 2008 & 15066 & 8.85 & 7.45 & 38.36 & $30.10 \%$ & $43.61 \%$ \\
\hline & 2009 & 15255 & 8.63 & 7.88 & 38.05 & $28.84 \%$ & $44.97 \%$ \\
\hline & 2010 & 15665 & 8.91 & 7.73 & 38.42 & $29.90 \%$ & $44.69 \%$ \\
\hline & 2011 & 16514 & 8.98 & 7.21 & 38.22 & $30.00 \%$ & $42.99 \%$ \\
\hline & 2012 & 16426 & 9.11 & 7.03 & 38.64 & $29.88 \%$ & $39.72 \%$ \\
\hline & 2013 & 15760 & 9.19 & 7.39 & 38.83 & $27.73 \%$ & $40.00 \%$ \\
\hline & 2014 & 15860 & 9.38 & 7.55 & 39.11 & $25.31 \%$ & $40.07 \%$ \\
\hline
\end{tabular}

Note: Adjusted by the GEIH expansion factor. For the consumer price index, December $2018=1.00$. Source: Author's calculations based on the GEIH.

The GEIH requests monthly wage and average hours worked in a week, used to calculate the point-in-time price of labor in the main job (table 2), to avoid a measure depending on labor supply decisions and the choice of holding more than one job. As suggested by DiNardo, Fortin, and Lemieux (1996):

The hourly wage measure used in this paper is thus more closely connected to theories of wage determination based on supply and demand that focus on the hourly price of labor. Similarly, the connection between the minimum wage and the hourly wage on the main 
job is more direct than the connection between the minimum wage and average weekly earnings on all jobs (p. 1006).

Table 2. Hourly Real Wage

\begin{tabular}{|c|c|c|c|c|c|c|}
\hline & \multirow{2}{*}{ March } & \multicolumn{5}{|c|}{ Log Hourly Real Wage } \\
\hline & & Legal Minimum & Mean & Median & Standard Deviation & Skewness \\
\hline \multirow{7}{*}{ Total } & 2008 & 7.75 & 7.66 & 7.71 & 0.66 & 0.02 \\
\hline & 2009 & 7.76 & 7.64 & 7.73 & 0.66 & -0.16 \\
\hline & 2010 & 7.78 & 7.69 & 7.74 & 0.69 & 0.06 \\
\hline & 2011 & 7.79 & 7.72 & 7.76 & 0.66 & -0.02 \\
\hline & 2012 & 7.81 & 7.74 & 7.81 & 0.68 & -0.15 \\
\hline & 2013 & 7.83 & 7.75 & 7.83 & 0.65 & -0.22 \\
\hline & 2014 & 7.85 & 7.81 & 7.85 & 0.64 & -0.16 \\
\hline \multirow{7}{*}{ Women } & 2008 & 7.75 & 7.63 & 7.74 & 0.74 & -0.10 \\
\hline & 2009 & 7.76 & 7.63 & 7.73 & 0.72 & -0.23 \\
\hline & 2010 & 7.78 & 7.67 & 7.75 & 0.74 & -0.10 \\
\hline & 2011 & 7.79 & 7.68 & 7.75 & 0.74 & -0.14 \\
\hline & 2012 & 7.81 & 7.69 & 7.81 & 0.76 & -0.24 \\
\hline & 2013 & 7.83 & 7.72 & 7.83 & 0.72 & -0.34 \\
\hline & 2014 & 7.85 & 7.77 & 7.85 & 0.72 & -0.26 \\
\hline \multirow{7}{*}{ Men } & 2008 & 7.75 & 7.68 & 7.69 & 0.61 & 0.18 \\
\hline & 2009 & 7.76 & 7.67 & 7.73 & 0.61 & -0.03 \\
\hline & 2010 & 7.78 & 7.71 & 7.72 & 0.65 & 0.23 \\
\hline & 2011 & 7.79 & 7.75 & 7.77 & 0.61 & 0.14 \\
\hline & 2012 & 7.81 & 7.77 & 7.81 & 0.62 & -0.01 \\
\hline & 2013 & 7.83 & 7.78 & 7.82 & 0.60 & -0.06 \\
\hline & 2014 & 7.85 & 7.84 & 7.85 & 0.59 & -0.01 \\
\hline
\end{tabular}

Note: Adjusted by the GEIH expansion factor.

Source: Author's calculations based on the GEIH.

In line with the literature, table 2 brings evidence of the procyclical behavior of mean hourly wages (Arango, Parra-Escobar, \& Pinzón-Giraldo, 2016). Legal hourly real minimum wage increases along the whole period, while mean real hourly wage behaves procyclically. Both forces imply that the gap between mean hourly wage and legal minimum wage was amplifying in contraction and narrowing at recovery; that gap reaches $12 \%$ in the through 
and $4 \%$ in the recovery. An indicator of that behavior of wages perception is the share of underemployment by income (table 1), which looks like it jumped a year after the trough and decreased quickly at the recovery phase.

When recovery is taking place, wage indicators improve, but once again, benefits associated with recovery appear unevenly distributed across female and male segments. Statistical indicators reported in table 2 allow to form some priors on wage distribution, standard deviation is relatively stable while skewness exhibits higher variation. That behavior calls for a deep look at the whole wages' distribution.

\section{Counterfactual and Decomposition of Trough and Recovery Wages}

\subsection{Decomposition}

The aim of this section is to perform a sequential decomposition (semiparametric wage density decomposition) that accounts for the changes in estimated kernel densities between the March 2008's trough $\left(\hat{f}_{T}\right)$ and the recovery point in March $2014\left(\hat{f}_{R}\right)$ :

$$
\hat{f}_{R}(w)-\hat{f}_{T}(w)
$$

The distribution of wages at trough - March 2009- looks like translations to the left of the recovery wage distribution -March 2014- (figure 2a). This procyclical wages distributions behavior can be a recovery wage distribution stochastically dominating (first order) trough wage distribution. To shed light on the understanding of those translations, wages distributions are decomposed in 1) cyclical demand and supply factors; 2) changes in workers' attributes; 3) changes and spillovers effects of minimum wage, and 4) a residual associated to seasonal and long-run effects on the labor market.

Statistical indicators in table 2 explain the shape of female and male distributions in figure $2 b$. Even though for female and male workforce distribution of wages at trough looks like translations to the left of the recovery wage distribution, figure $2 \mathrm{~b}$ provides a picture of an uneven recovery process. In trough and recovery, the female hourly wage schedule can be thought as a median preserving spread of the male one -i.e., female hourly wages have the same median as male ones, but the first exhibit higher variance (table 2). 


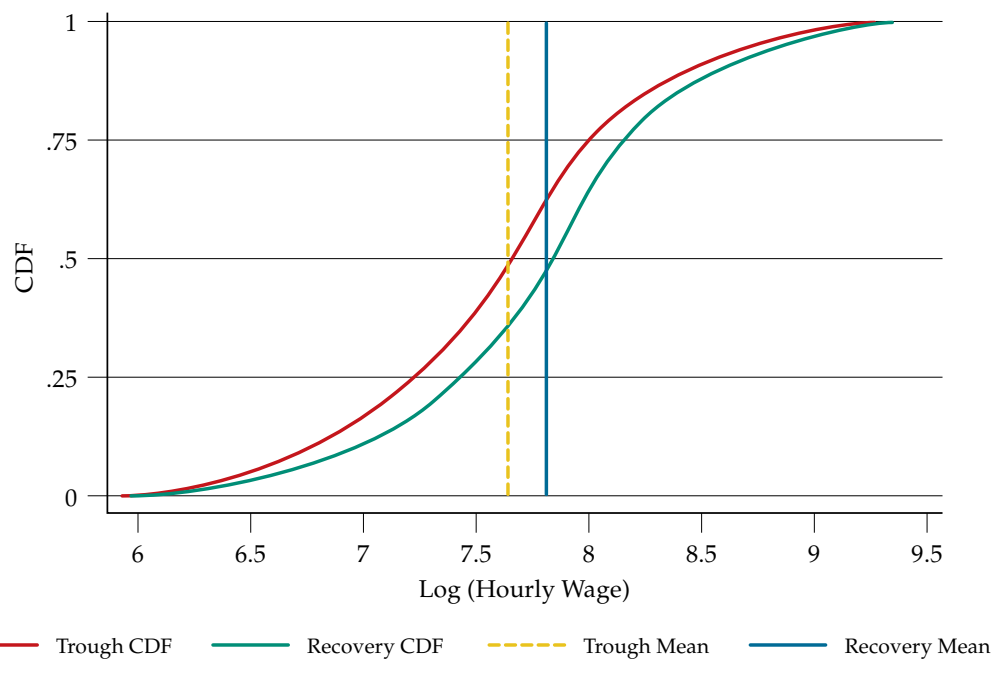

Figure 2a. Kernel CDF, Trough (March 2009) and Recovery (March 2014). Source: Author's calculations based on the GEIH.

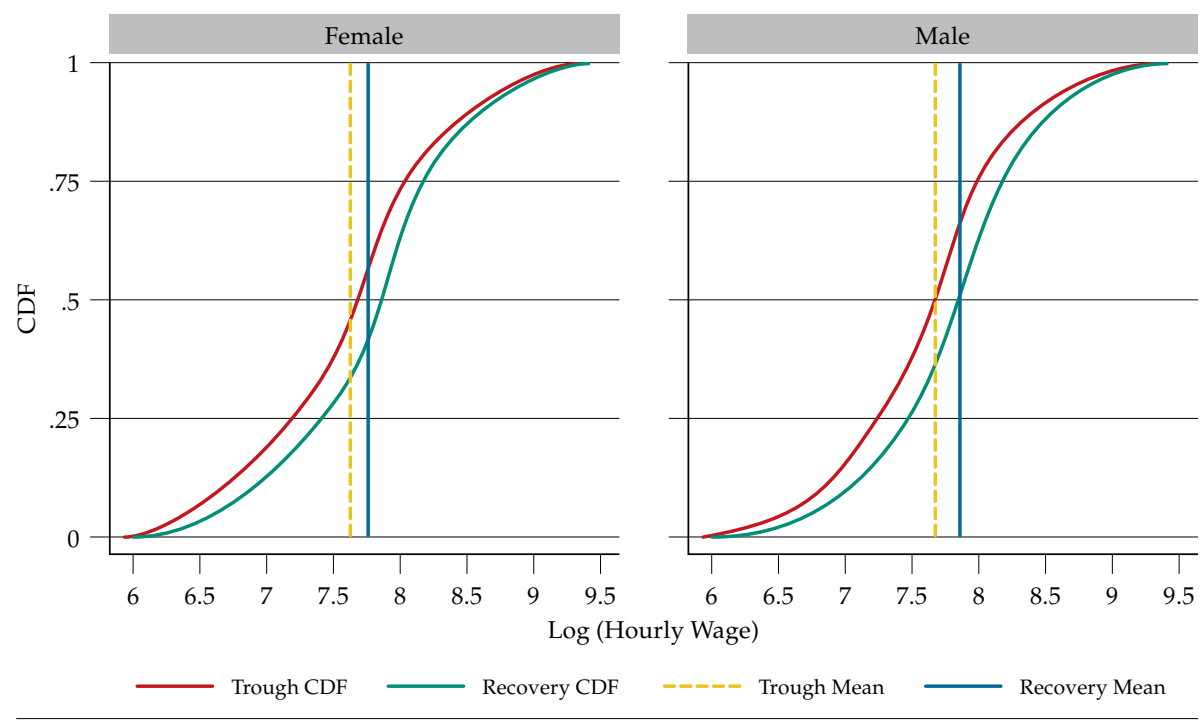

Figure 2b. Female and Male Kernel CDF, Trough (March 2009) and Recovery (March 2014)

Source: Author's calculations based on the GEIH. 


\subsection{Supply and Demand}

Traditional aggregate studies exploring real wages behavior over the cycle use an identification strategy, depending on the correlation between wages and a cyclical indicator. Abraham and Haltiwanger (1995) characterize that kind of studies as those, estimating:

$$
w_{t}=\alpha+\beta C_{t}+\varepsilon_{t}
$$

Where $w_{t}$ is a measure of aggregated real wages, and $C_{t}$ is a cyclical indicator (see Arango et al., 2006, for Colombian the case.) Nevertheless, over the cycle, demand and supply changes and firms' responses to cyclical innovations that may not be synchronized are experienced. Thus, there will be changes in the composition of the employed workforce during the cycle. To catch up those effects, this paper divides the workforce into 24 gendereducation-age cells. Thus, each cell encapsulates male and female workforce by a measure of potential experience. Table 3 shows data composition for the total workforce (unemployed and employed) and the way cells are defined.

Table 3. Share of Labor Force by Cell: March 2008

\begin{tabular}{cccccc}
\hline Female & & \multicolumn{5}{c}{ Age } \\
\hline Education & $\leq 26$ & $(26,36]$ & $(36,47]$ & $>47$ & Total \\
\hline$\leq 6$ & $1.54 \%$ & $2.04 \%$ & $3.76 \%$ & $4.76 \%$ & $12.11 \%$ \\
$(6,13]$ & $6.96 \%$ & $5.01 \%$ & $4.62 \%$ & $2.21 \%$ & $18.80 \%$ \\
$>13$ & $2.17 \%$ & $3.42 \%$ & $2.79 \%$ & $1.53 \%$ & $9.91 \%$ \\
Total & $10.67 \%$ & $10.47 \%$ & $11.17 \%$ & $8.51 \%$ & $40.82 \%$ \\
\hline Male & & & Age & & \\
\hline Education & $\leq 26$ & $(26.36]$ & $(36.47]$ & $>47$ & Total \\
\hline$\leq 6$ & $3.79 \%$ & $4.13 \%$ & $6.25 \%$ & $9.19 \%$ & $23.36 \%$ \\
$(6,13]$ & $10.00 \%$ & $6.67 \%$ & $5.84 \%$ & $4.11 \%$ & $26.61 \%$ \\
$>13$ & $1.81 \%$ & $2.96 \%$ & $2.46 \%$ & $1.98 \%$ & $9.20 \%$ \\
Total & $15.59 \%$ & $13.76 \%$ & $14.55 \%$ & $15.28 \%$ & $59.18 \%$ \\
\hline
\end{tabular}

Note: Adjusted by the GEIH expansion factor.

Source: Author's calculations based on the GEIH.

For each cell, a measure of supply and demand (SDjt) was calculated, defined as the share of the total matched workforce in cell $j$. The oLs are 
used to estimate the shift in the mean cell wage, correlated with changes in supply and demand of labor, and IMACO, which is used as a cyclical indicator:

$$
\Delta w_{j t}=\alpha_{j} \Delta S D_{j t}+\beta_{j} I M A C O_{t}+e_{j t} j=1 \ldots 24
$$

The oLs use monthly data over the period 2008:03 - 2014:03. At each March belonging to this period, figures $3 \mathrm{a}$ and $3 \mathrm{~b}$ display $\Delta w_{j t}$ actual and fitted through the oLs estimation of (2). Timing depends upon diffusion indexes, as a consequence, figures $3 a$ and $3 b$ make evident through shifts of wage by cell that "there is a rough balance between expanding and contracting forces" (Moore, 1983).
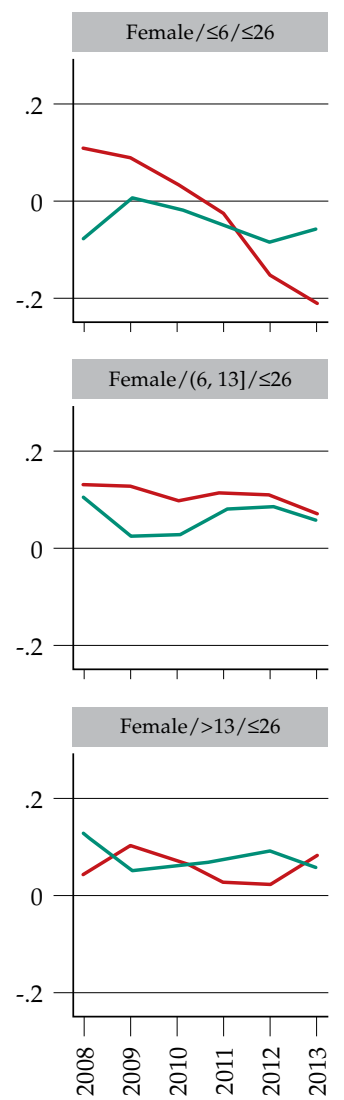
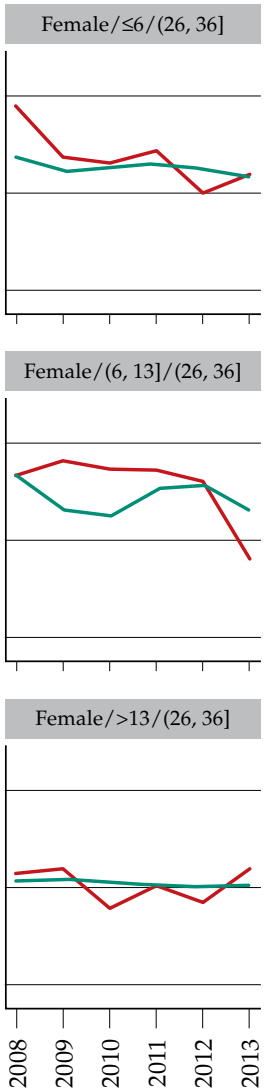
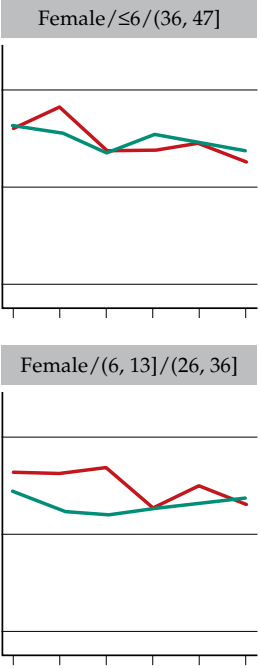

Female $/>13 /(36,47]$

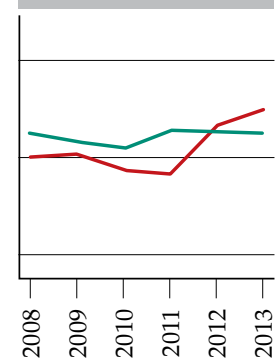

March, year

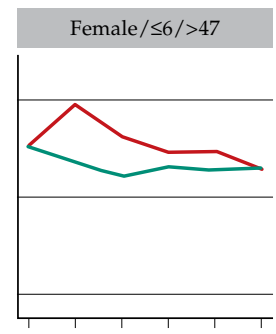

Female $/(6,13] />47$

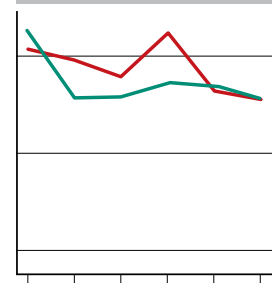

Female $/>13 />47$

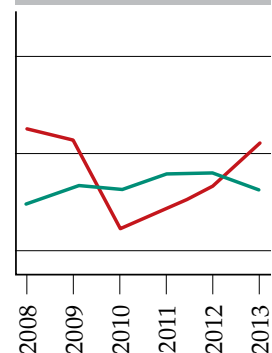

$\Delta \mathrm{w}:$ Actual $\Delta \mathrm{w}:$ Fitted

Figure 3a. Source: Author's estimations based on the GEIH. 

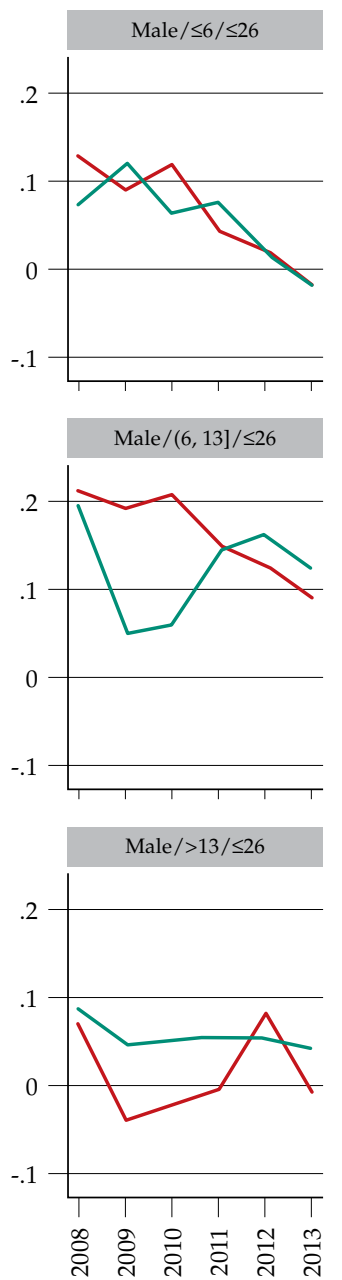
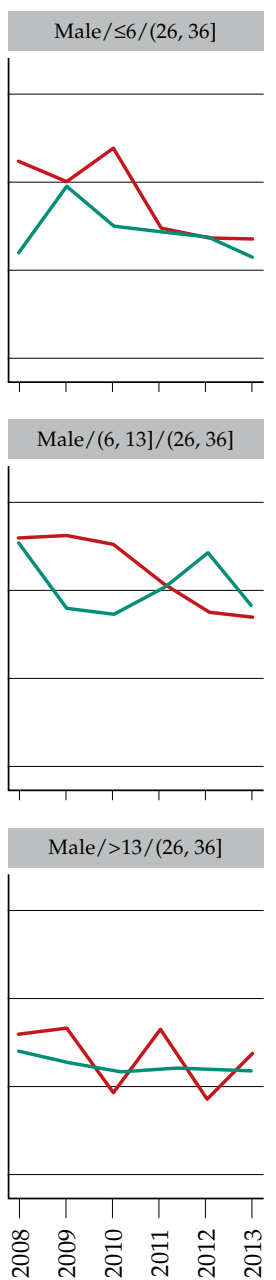

March, year
Male/ $\leq 6 /(36,47]$

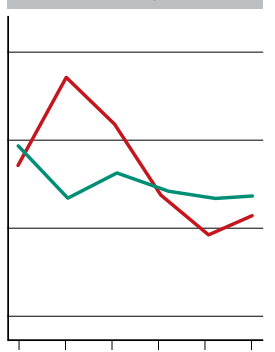

Male $/(6,13] /(36,47]$
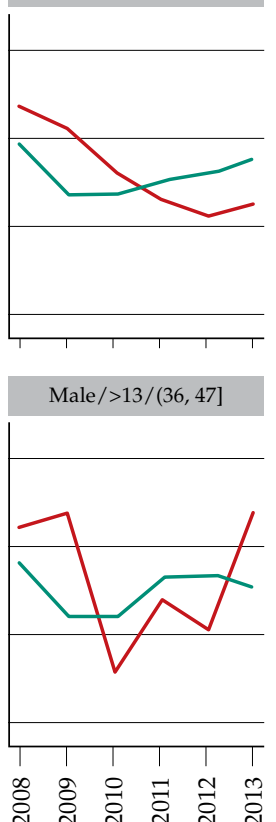

空

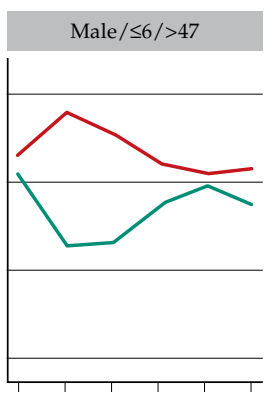

Male $/(6,13] />47$

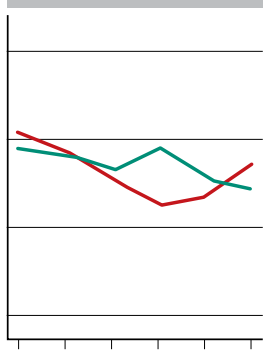

Male/ $>13 /(36,47]$

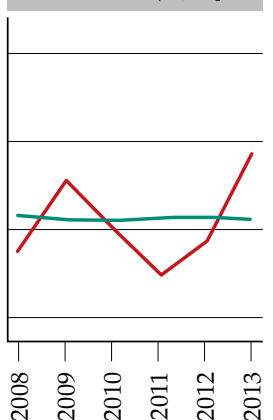

$\Delta \mathrm{w}$ : Actual $\Delta w:$ Fitted

Figure 3b. Source: Author's estimations based on the GEIH.

In order to get the counterfactual distribution, if supply and demand and cyclical indicators are set as in the recovery level, the Kernel estimation is carried over $w_{R}-\Delta \widehat{w}_{j R}$.

The differences between those series are intended to account for the wages' component by cell, which is orthogonal to cyclical demand and supply cell factors, and the broad indicator. By discounting the estimated change in wages, it is possible to compare findings on the relative importance of 
minimum wages with the rest of the literature that has focused heavily on supply and demand, by neither overstating the importance of factors nor ignoring supply and demand considerations.

In this line, as Barlevy and Tsiddon (2004) claim, the next step is incorporating skills updating in order to capture a secular trend in the form of technological bias driving wages (Bound \& Johnson, 1992).

\subsection{Attributes}

In line with Mincerian wage equations, a function on attributes $x$ : $H(x)$ is built to explore changes in attributes. $H$ includes polynomial forms of tenure, age, and educational attainment (years of schooling). In addition, dummies for gender, head household, marital status, and underemployment by income are included (Arango, Escobar, \& Monsalve, 2013). Regional and sectorial differentials in wages are assumed to be captured through dummies for 15 IsIC sectors and 23 for department. At a point in time and given those observable attributes of workers, the response of wage schedule to innovations is estimated by Kernel estimation over:

$$
w_{T}-\Delta \widehat{w}_{j R}
$$

Using the reweighting function:

$$
\psi_{x}(x)=\frac{\operatorname{Pr}\left(t_{x}=T \mid x\right) \operatorname{Pr}\left(t_{x}=R\right)}{\operatorname{Pr}\left(t_{x}=R \mid x\right) \operatorname{Pr}\left(t_{x}=T\right)}
$$

The probability of being in the phase $t$ (trough or recovery), given individual attributes $x$, is estimated using a logit (robust) model:

$$
\operatorname{Pr}\left(t_{x}=t \mid x\right)=\operatorname{Pr}\left(\in>-\beta_{t}^{\prime} H(x)\right)=1-\Phi\left(-\beta_{t}^{\prime} H(x)\right)
$$

Function $\Phi$, as defined by the standard logit model (see DiNardo, Fortin, \& Lemieux, 1196, equation 11). kernel estimation depends on the vector of parameters $\beta_{t}^{\prime}$ whose estimation makes the DFL methodology a semi-parametric approach. 


\subsection{Minimum wage}

In Colombia, minimum wage is set on a monthly base for 48 working hours per week. Minimum wage is increased annually in a negotiation among business associations, unions, and government based on inflation expectations and productivity growth. Mondragón and Peña (2012) found evidence that the workday increases during recessions in response to the increase in labor market rigidities associated to minimum wages in the formal sector. As figure 4 shows, the percentage of minimum monthly wage earners reporting 40 hours per week exhibits a procyclical behavior suggesting that nominal rigidities induce a spillover on labor contracts nominally anchored to law. Along the recovery phase, an increasing mass of workers in the middle also gets bumped up along with the lowest paid. In order to capture that spillover, in the kernel counterfactual estimation, minimum wage is calculated for 40 working hours per week instead of 48:

$$
m_{t} \equiv \frac{12 M_{t}}{40 * 52}
$$

Where $M_{t}$ is monthly minimum wage.

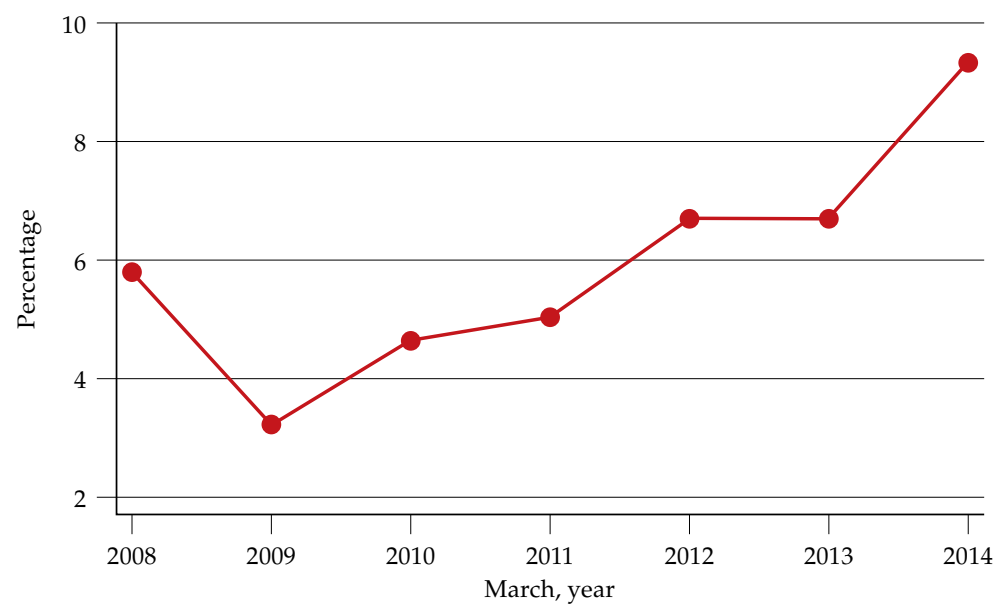

Figure 4. Percentage of Minimum Monthly Wage Earners Reporting 40 Hours Workday per Week

Source: Author's calculations based on the GEIH. 
Once again, to estimate the counterfactual "density that would have prevailed if individual... [, supply and demand factors, cyclical indicator, and minimum wage] had remained at their ... [trough] level and workers had been paid according to the wage schedule observed in... [recovery]" (DiNardo, Fortin, \& Lemieux, 1996, p. 1011) the reweighting function is

$$
\psi^{\prime}\left(z, m_{R}\right)=\frac{\operatorname{Pr}\left(t_{w}=R \mid z, w \leq m_{R}\right) \operatorname{Pr}\left(t_{z}=T\right)}{\operatorname{Pr}\left(t_{w}=T \mid z, w \leq m_{R}\right) \operatorname{Pr}\left(t_{z}=R\right)}
$$

The probability of being in the phase $t$ (trough or recovery), given individual attributes $z$, is estimated using a logit model by pooling the data with real hourly wages lower (higher) than $m_{R}$.

\subsection{Results of Sequential Decomposition}

Figure 5a presents actual densities in trough (point line) and recovery (solid line) whose differences are intended to be explained throughout decomposition. As it is known, DFL decomposition allows visually inspecting factors to explain changes in distributions. In this case, sequential decomposition is supposed to induce left translations of kernel density at recovery up to kernel density at trough.

As figure 5b shows, supply and demand cyclical factors translate kernel density at recovery to the left, which means that wage policy is updated by incorporating cell responses to the aggregate component of the cycle, and demand and supply adjustments.

Figure $5 c$ decomposes the skills updating, associated with the secular technological bias, which again looks like a left translation of adjusted kernel density. In line with the literature, explanations of change in the distribution of wages can be associated with differentials by educational attainment and the gender gap, that is "a combination of skilled-labor-biased technical change and changes in unmeasured labor quality" (Bound \& Johnson, 1992, p. 389).

Once minimum hourly wage is set, based on 40 working hours per week, figure $5 \mathrm{~d}$ represents a translation on adjusted kernel by discounting the concentration of workers at the level of the spillover minimum wage. Adjusted kernel suggests that raising the minimum wage has effects in giving form to the bottom end of the income distribution, not just by truncating "the income distribution from the left by forcing employers to pay the lowest earners at a 
specified minimum" (Dolton et al., 2012). Instead, the minimum hourly wage defines a cutoff to look for changes in the bottom of the distribution. Figure $5 e$ shows the remaining unexplained component associated with seasonal and long-run effects on the labor market.

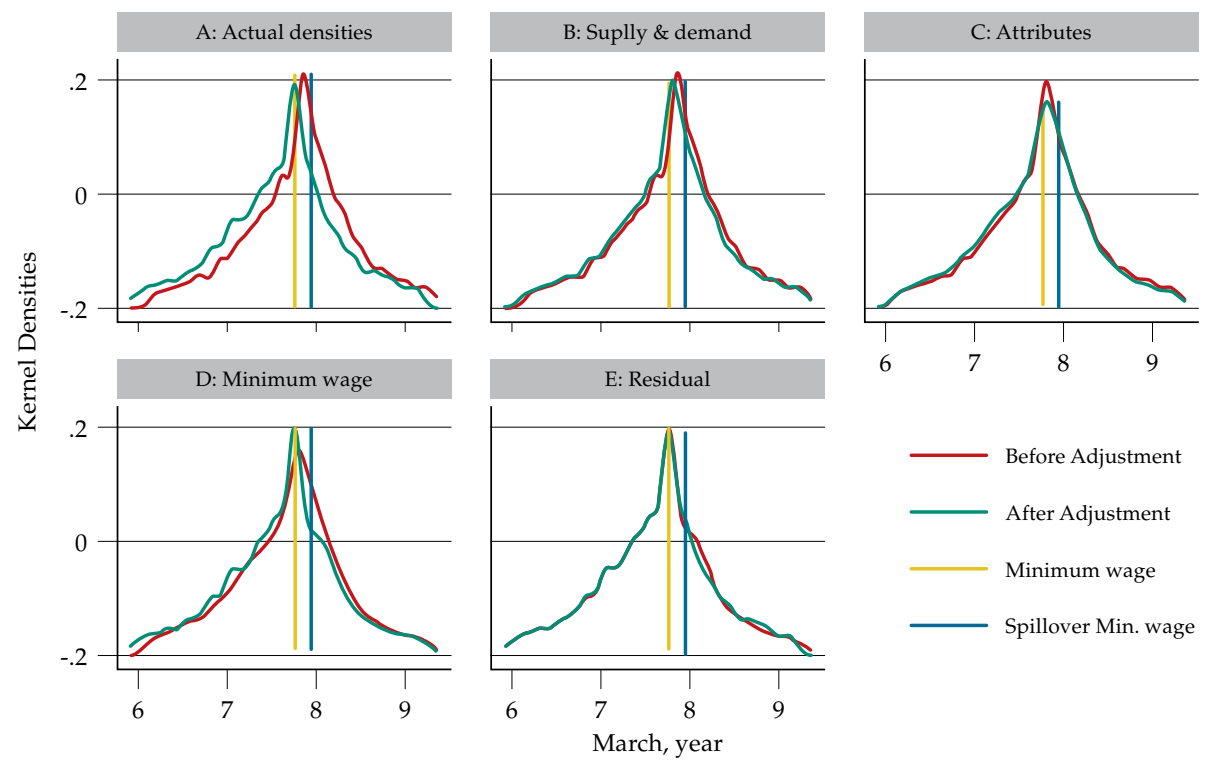

Figure 5. Density of Wage at Trough (March 2009) Adjusted by Indicated Factors Source: Author's calculations based on the GEIH.

Figure 6a displays the actual change in distributions, which in the absence of changes, would be a flat line in zero. In general, the resulting differences are associated with changes in the moments of a distribution. A huge difference lies between the minimum legal hourly wage and the spillover minimum hourly wage (vertical dotted lines). Figures $6 b, 6 c$, and $6 d$ show that once each factor is sequentially applied, the information updated by each one renders a flatter difference. 


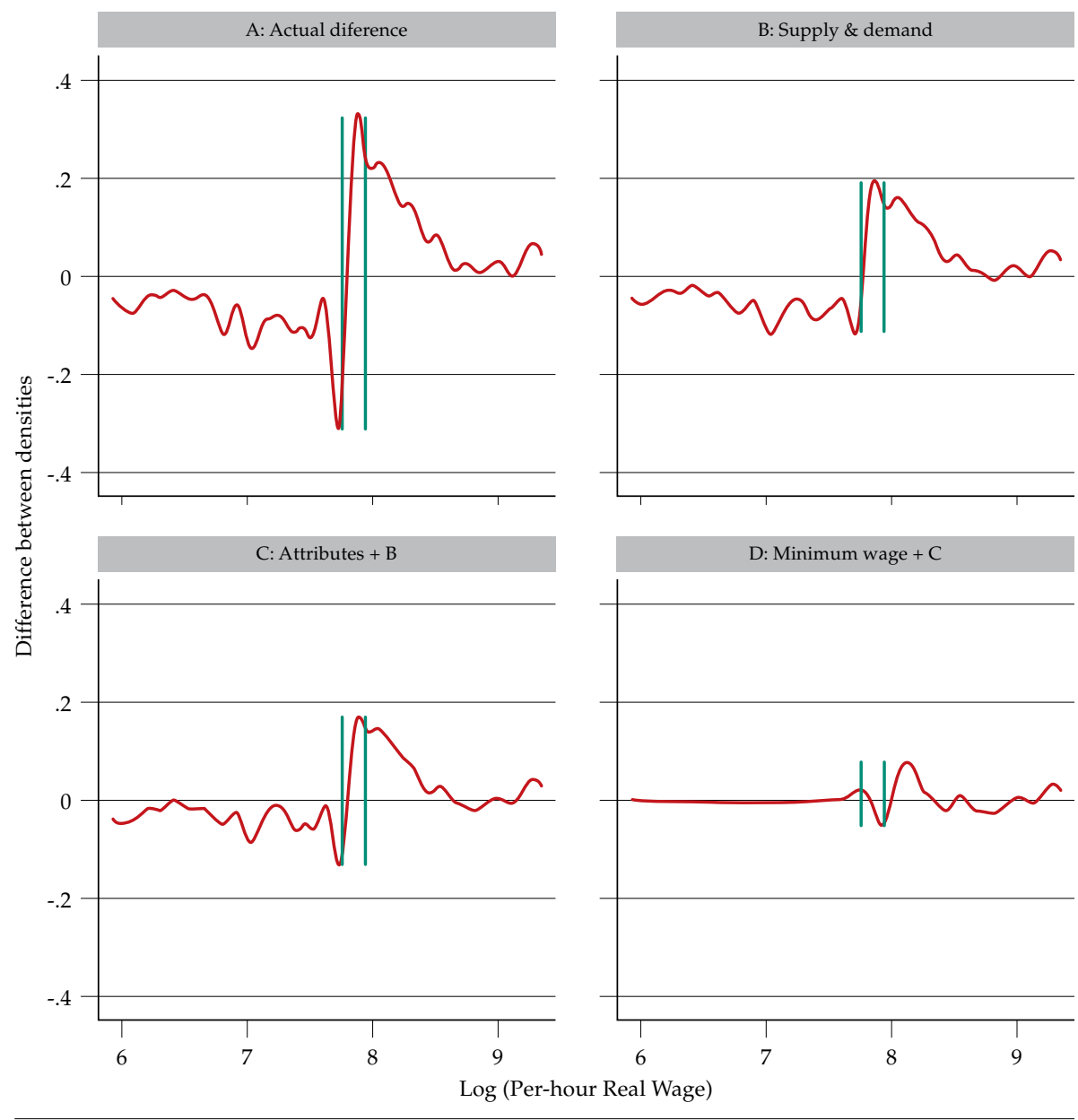

Figure 6. Differences between the Recovery Density of Hourly Real Wages Adjusted by Indicated Factor and the Trough Density Source: Author's calculations based on the GEIH.

\section{Discussion and Concluding Remarks}

During a cycle phase, the wage schedule, mapped by a kernel, results from a bargain process. First, firms arrive at the labor market not only establishing wage policies, which reflect mark-ups, but also offering different wages to workers with similar observable attributes. In contrast, workers' pursuit of a wage based on the subjective valuation of their own observable and unobservable attributes. Once a deal is reached, a match between an employer and a worker is to set the negotiated wage up. Firms go to the market to 
validate their markup given their bargain power, in the same way, workers behave to validate the subjective valuation of their attributes. The result, at the market, depends upon the fact that firms' strategies are complementary while workers' strategies are substitutes. Therefore, employers increase their bargain power in a contraction (lower demand), while workers reduce their power by crowding the market (higher offer). The tightening of labor markets ends up shifting wage distribution to the left. In this way, "shocks that affect the bargaining position of workers also affect the distribution of income" (Quadrini \& Ríos-Rull, 2014, p. 1257).

Table 4 reports Kullback-Leibler J-Index for each March during the cycle. It shows that divergence between distributions vanished as recovery took place around 2011. This behavior supports the robustness of the sequential decomposition.

Table 4. Kullback-Leibler J-Index

\begin{tabular}{|c|c|c|c|c|c|}
\hline March & J-Index & $S \& D$ & Attributes & $\begin{array}{l}\text { Minimum } \\
\text { Wage }\end{array}$ & Residual \\
\hline \multirow{2}{*}{2008} & \multirow{2}{*}{0.1393} & 0.1169 & 0.0025 & 0.0076 & 0.0123 \\
\hline & & (83.92) & (1.77) & $(5.45)$ & $(8.87)$ \\
\hline \multirow{2}{*}{2009} & \multirow{2}{*}{0.1577} & 0.0859 & 0.0222 & 0.0406 & 0.0090 \\
\hline & & (54.46) & (14.07) & (25.77) & (5.70) \\
\hline \multirow{2}{*}{2010} & \multirow{2}{*}{0.1100} & 0.0564 & 0.0134 & 0.0293 & 0.0109 \\
\hline & & (51.25) & (12.18) & (26.63) & (9.94) \\
\hline \multirow{2}{*}{2011} & \multirow{2}{*}{0.0660} & 0.0518 & 0.0040 & 0.0042 & 0.0060 \\
\hline & & (78.47) & $(6.06)$ & $(6.37)$ & (9.10) \\
\hline \multirow{2}{*}{2012} & \multirow{2}{*}{0.0491} & 0.0372 & -0.0025 & 0.0099 & 0.0045 \\
\hline & & (75.78) & $(-5.02)$ & (20.05) & (9.19) \\
\hline \multirow{2}{*}{2013} & \multirow{2}{*}{0.0366} & 0.0232 & -0.0008 & 0.0105 & 0.0038 \\
\hline & & (63.27) & $(-2.26)$ & (28.62) & (10.37) \\
\hline
\end{tabular}

Note: J-index is calculated by replicating DFL sequential decomposition respect recovery peak (March 2014). Parentheses underneath display percentage of the total change associated to each factor in the sequential decomposition.

Source: Author's calculations based on the GEIH.

Up to here, results confirm the importance of cyclical supply and demand factors in shaping wage distribution in the cycle (figures $5 \mathrm{~b}$ and $6 \mathrm{~b}$ ), even if the divergence between distributions is slight (table 4). As expected, J-index 
decreases as the economy reaches the recovery, but supply and demand still are the main factors in the decomposition. Firms' wage policy is updated by incorporating cell responses to aggregate component of the cycle, and demand and supply adjustments. Remember that, first, each cell encapsulates male and female workforce by a measure of potential experience, and, second, female hourly wage schedule can be thought as a median preserving spread of male one; thus, wage policy updating induces an uneven recovery process. This result contrasts with evidence suggesting that female earnings are non-responsive to macroeconomic developments (Blank, 1989).

Figures $5 \mathrm{c}$ and $6 \mathrm{c}$ support the hypothesis of skills updating, acting as a secular factor affecting fluctuations of the wage distribution in a particular cycle (Barlevy \& Tsiddon, 2004). Even tough table 4 shows the percentage of total change associated with attributes drops, since 2011, the secular factor shapes the trend at the beginning of the recovery phase.

Evidence suggests that there is a positive spillover from minimum monthly wage on hourly wages, explaining around $25 \%$ of the divergence between distributions at the trough and at the recovery peak (table 4). This effect of minimum wage deserves a detailed analysis. Debate on the effects emerging from minimum wage can be traced to Card and Krueger's (1994) quasiexperimental setting, in which they found that minimum wage increases can result in net job gains rather than the losses predicted by conventional wisdom. There are a large number of studies on the labor market impact of the minimum wage, especially on the impact on employment (for a review of the literature see Neumark \& Wascher, 2008). In Colombia, papers focus on employment quality, emphasizing the informal-formal composition of labor force (Mondragón \& Peña, 2012).

One reason for the relevance that minimum wage takes during a business cycle is the fact that it implies some degree of wage stickiness and, as a consequence, a more volatile income distribution (Quadrini \& Ríos-Rull, 2014). As Mondragón and Peña (2012) pose, the formal sector cannot respond to cyclical fluctuations because of the presence of market rigidities linked to minimum wages. In Colombia, the minimum monthly wage is the fiftieth percentile of the monthly wage, but it is lower than the mean monthly wage. In the approach proposed here, the minimum hourly wage defines a cutoff to look for changes in the bottom of the distribution and to understand the role played by informal-formal interactions in shaping this bottom.

Having this long debate in mind, the sequential approach taken here tries to address two potential caveats. First, the decomposition incorporates responses of wage schedule by cells looking for a narrower definition of skills groups and gives account of the role of individual attributes. The 
main reason to proceed in this way is to avoid what Teulings (2001) calls the minimum wage paradox, which is mainly due to the aggregation of workers in broader skill groups; who states that "an increase in the minimum wage would then produce a slight reduction in low-skilled employment and, as a result of it, a large wage increase for the low-skilled workers who remain employed" (p. 1). Second, a detectable effect from the minimum wage on the wage distribution depends on the degree of compliance with the minimum wage and the number of workers directly affected (Dickens \& Manning, 2004). As mentioned above, the setting of the spillover minimum wage allows accounting for an increasing mass of workers in the middle who also get bumped up along with the lowest paid (figures $5 \mathrm{~d}$ and $6 \mathrm{~d}$ ).

Findings shed light on the way wage distribution can be decomposed in 1) cyclical demand and supply factors; 2) changes in the workers' attributes; 3) changes and spillover effects of minimum wage, and 4) a residual associated to seasonal and long-run effects on the labor market. Even though, there are still be some potential caveats linked to general equilibrium effects, the decomposition provides visual evidence that contributes to understanding the process shaping the wage schedule along the business cycle.

\section{References}

Abraham, K. G., \& Haltiwanger, J. C. (1995). Real Wages and the Business Cycle. Journal of Economic Literature, 33(3), 1215-1264. Retrieved from https://www.jstor.org/stable/2729121

Alfonso, V., Arango, L. E., Arias, F., Cangrejo, G., \& Pulido, J. D. (2012). Ciclos de negocios en Colombia: 1975-2011. Borradores de Economía, (651), 1-57.

Arango, L. E., Escobar, D., \& Monsalve, E. (2013). Subempleo por ingresos y funcionamiento del mercado de trabajo en Colombia. Revista Desarrollo y Sociedad, (72), 157-203. https://doi.org/10.13043/DYS.72.4

Arango, L. E., Parra-Escobar, F. F., \& Pinzón-Giraldo, A. J. (2016). El ciclo económico y el mercado de trabajo en Colombia: 1984-2014. Ensayos sobre Política Económica, (34), 206-228. https://doi.org/10.1016/j.espe.2016.08.002

Banco de la República. (2019, 02 15). Estadísticas: Banco de la República. Retrieved from https://www.banrep.gov.co/es/-estadisticas

Barlevy, G., \& Tsiddon, D. (2004). Earnings inequality and the business cycle. NBER Working Paper Series, 1-43. https://doi.org/10.3386/w10469

Barsky, R., \& Solon, G. (1989). Real wages over the business cycle. NBER Working Paper Series, (2888), 1-46. https://doi.org/10.3386/w2888 
Blank, R. M. (1989). Disaggregating the effect of the business cycle on the distribution of income. Economica, New Series, 56(222), 141-163. Retrieved from https://www.jstor.org/stable/2554036

Bound, J., \& Johnson, G. (1992). Changes in the structure of wages in the 1980's: An evaluation of alternative explanations. The American Economic Review, 82(3), 371-392.

Card, D., \& Krueger , A. B. (1994). Minimum Wages and Employment: A case study of the fast-food industry in New Jersey and Pennsylvania. The American Economic Review, 84(4), 772-793.

Dickens, R., \& Manning, A. (2004). Has the national minimum wage reduced UK wage inequality? Journal of the Royal Statistical Society Series A, 167(4), 613-626. https://doi.org/10.1111/j.1467-985X.2004.aeI2.x

DiNardo, J., Fortin, N. M., \& Lemieux, T. (1996). Labor market institutions and the distribution of wages, 1973-1992: A semiparametric approach. Econometrica, 64(5), 1001-1044. https://doi.org/10.2307/2171954

Dolton, P., Rosazza Bondibene, C., Schivardi, F., \& Spinnewijn, J. (2012). The international experience of minimum wages in an economic downturn. Economic Policy, 27(69), 99-142. https://doi.org/10.1111/j.14680327.2011.00278.x

Kamil, H., Pulido, J. D., \& Torres, J. L. (2010). El "IMACo": un índice mensual líder de la actividad económica en Colombia. Borradores de Economía, (609), 1-40.

Mondragón, C., \& Peña, X. (2012). Rigideces laborales y salarios en los sectores formal. In L. E. Arango, \& F. Hamman (Eds.), El mercado de trabajo en Colombia: hechos, tendencias e instituciones (pp. 1-874). Bogotá: Banco de la República.

Moore, G. H. (1983). Business Cycles, Inflation, and Forecasting. Ballinger: G. H. Moore, Ed.

Neumark, D., \& Wascher, W. L. (2008). Minimum wages. Cambridge: MIT Press. Quadrini, V., \& Ríos-Rull, J.-V. (2014). Inequality in macroeconomics. In A. Atkinson \& F. Bourguignon (Eds.), Handbook of Income Distribution. Volume $2 B$ (pp. 1229-1302). North Holland.

Teulings, C. N. (2001). Aggregation Bias in elasticities of substitution and the minimum wage paradox. International Economic Review, 41(2), 359-398. https://doi.org/10.1111/1468-2354.00067 